Paideusis

\title{
The Child Seen as the Same or the Other? The Significance of the Social Convention to the Pedagogical Relation
}

\section{Tone Saevi and Heidi Husevaag}

Volume 18, Number 2, 2009

URI: https://id.erudit.org/iderudit/1072330ar

DOI: https://doi.org/10.7202/1072330ar

See table of contents

Publisher(s)

Canadian Philosophy of Education Society

ISSN

0838-4517 (print)

1916-0348 (digital)

Explore this journal

Cite this article

Saevi, T. \& Husevaag, H. (2009). The Child Seen as the Same or the Other? The Significance of the Social Convention to the Pedagogical Relation. Paideusis, 18(2), 29-41. https://doi.org/10.7202/1072330ar
Article abstract

The aim of this article is to explore the lifeworld of children as they experience everyday conventional situations where proper behaviour is expected and to understand the significance of the social convention to the pedagogical relation between adult and child. Based on interviews with adults recalling pedagogical episodes of handshaking, waiting, and thanking someone, we describe and interpret narrative examples by the light of Continental phenomenological pedagogy. Including children in the traditions of a society by exposing them to situations where conventional behaviour and adherence to social norms are expected is an unavoidable ingredient of pedagogical practice. Adults often expect children to adapt to social conventions simply by being introduced to them, and at the same time as adults we are somehow prevented from seeing the meaning of the situation for the child by our grown-up-ness and the conventional quality of the situation. The socialization of children, including the transfer of conventionally proper behaviour from one generation to the next, introduces ethical and pedagogical dilemmas. We suggest that although social conventions of proper behaviour are desirable and important factors of socialization for the child, the social convention itself can be a pedagogical impasse that anticipates homogeneity and assimilation and renders difficult a pedagogically caring practice.
(C) Tone Saevi, Heidi Husevaag, 2009

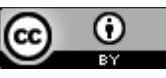

This document is protected by copyright law. Use of the services of Érudit (including reproduction) is subject to its terms and conditions, which can be viewed online.

https://apropos.erudit.org/en/users/policy-on-use/ 


\section{The Child Seen as the Same or the Other? The Significance of the Social Convention to the Pedagogical Relation}

TONE SAEVI and HEIDI HUSEVAAG
Norwegian Teacher Academy, Bergen, Norway

The aim of this article is to explore the lifeworld of children as they experience everyday conventional situations where proper behaviour is expected and to understand the significance of the social convention to the pedagogical relation between adult and child. Based on interviews with adults recalling pedagogical episodes of handshaking, waiting, and thanking someone, we describe and interpret narrative examples by the light of Continental phenomenological pedagogy. Including children in the traditions of a society by exposing them to situations where conventional behaviour and adberence to social norms are expected is an unavoidable ingredient of pedagogical practice. Adults often expect children to adapt to social conventions simply by being introduced to them, and at the same time as adults we are somehow prevented from seeing the meaning of the situation for the child by our grown-up-ness and the conventional quality of the situation. The socialization of children, including the transfer of conventionally proper behaviour from one generation to the next, introduces etbical and pedagogical dilemmas. We suggest that although social conventions of proper behaviour are desirable and important factors of socialization for the child, the social convention itself can be a pedagogical impasse that anticipates homogeneity and assimilation and renders difficult a pedagogically caring practice.

\section{Introduction}

Lize Stilma's poem, 'Lydia', from the book Portraits (1985, p. 39), tells the story of a mother who has been deprived of her only child by the authorities, and every evening, with broken heart, at twilight, she sits on the porch calling out her child's name. Her neighbours have long since ceased to listen but still Lydia's voice drifts every night into their homes along with the gentle breeze,

No one heard the despair in her voice any longer.

No one felt pity any more.

Lydia had been crying her evening cries for so many years!

It had become as insignificant as the yapping of a farmyard dog.

(C) Copyright 2009. The authors, Tone Saevi and Heidi Husevaag, assign to Paideusis the right of first publication and educational and non-profit institutions a non-exclusive license to use this document forpersonal use and in courses of instruction provided that the article is used in full and this copyright statement is reproduced. Any other usage is probibited without the express permission of the authors. 
Children and strangers would sometimes ask the meaning of her calling.

The tale was told with words long drained of empathy.

They would explain that crazy Lydia had a baby, many years ago.

Just imagine, Lydia a baby!

The city people hear the moan of the poor woman every evening, but they take no notice of their hearing. They no longer discern the real meaning of what they hear, and in the same way that one can see unseeingly and smell inodorously, one also might hear deafly. The people in Lydia's neighbourhood hear the echo of her voice, but they do not take in the meaning of it. "The echo of meaning has become meaningless, useless, a shade of noise not reverberating in the hearts of the listeners," (Saevi, 2005, p. 186). They have become so accustomed to Lydia's desolate grief that they unknowingly protect themselves against the demand of the situation by turning a conventionally deaf ear to it.

The hearing that has lost its ability to discern and make sense of what is heard seems to have essential traits in common with a custom, a habit, that which we know as a social convention. The social convention is no longer consciously taken notice of but remains in the unreflective or prereflective twilight zone of action. Social conventions, like social norms and routines, protect our relationships by rendering them unheeded, smooth and easy. Løgstrup (1971/1997) asserts that social conventions can cover up our ability to respond, because "we are usually able to conform to these directives without even having to consider the other person, much less take care of his [or her] life" (p. 58). Considering our focus on the significance of the social convention for the relation between adult and child, the following questions seem to be relevant. How do social conventions protect and also expose the child? How does the child experience adult conventions of proper behaviour and how does the 'conventionalized' adult understand the child? What is the significance of social conventions in pedagogy and the reverse, how might pedagogy influence social conventions?

In this article, based on empirical descriptions of relationships between the child and the adult in ordinary everyday pedagogical situations, we reflect phenomenologically on the meaning of conventions of proper behaviour to pedagogy. Social conventions are implicit in almost everything we do and say as well as in our ways of being and acting. The experiential material chosen for phenomenological reflection was drawn from these traditionally unattended to areas of everyday life where our social conventions reside. Our point of departure is three "anecdotes" (van Manen, 1989, 1997) shared by adults, as they recall situations from their childhoods where they encountered experientially the meaning of a social convention as an adult tacitly approved act. The anecdotes depict the lived meaning for a child of the convention of shaking hands, of waiting for mother, and of thanking another for a meal. Our intention is to explore the pedagogical significance of the convention of proper behaviour of children through these experiential descriptions.

Etymologically, the term 'convention' stems from the Latin word convenire, meaning to unite, to be suitable, to agree, from com 'together' + venire 'to come.' A convention is a common agreement of conduct, manners and ways of being and doing that over time have become incarnated in our body, senses and movements and thus have somehow come to reside outside our intentional actions. The convention is part and parcel of our relational life thus it is basically non-reflective and unintended by us. Conventions have developed for various cultural and social reasons, sometime in the past, within a certain tradition or sub-tradition, and are part of our belonging to a particular culture (Løgstrup, 1971/1997). In other words, tradition is at least partly built up by common agreements or social conventions that the members of a particular society consent to and are familiar with—although for the most part, in a pre-reflective and non-cognitive manner. Conventions within a tradition thus, are habitual, customary and ritual practices rather than intentional and calculated predetermined acts of everyday-life. Conventional habitual seeing that once was reflective, turns over time into a fairly unintended practice that tends to envelop our reflective perception rather than allowing us to reflect on our actions. Conventional inattention, like the unrecognized deaf hearing of Lydia's voice by those around her, was once alertly heard, but has through time become an act of custom and habit. Hence, 
convention cannot be attentive to its own existence in the moment of being rendered, or it would not be a convention. One might suggest that convention is before it is reflected on (if reflected on at all), and, like being, convention in the very moment of absorbed action, is not aware of itself (Saevi, 2005, p. 169). Conventions thus are hidden to us in the very act of being performed, and at the same time influence our being and acting regularly and profoundly. In pedagogical practice, cultural and social conventions are intertwined with our very being with children, and are presented to children directly through our embodied presence together with them-through our ways of looking, our gestures, and expressions, as well as the ways in which we relate to ourselves, to time, to space and other persons. In short, social conventions of proper behaviour are present in all pedagogical situations, and as we suggest here can be expressly explored in pedagogical relational practices in children's experiences of greeting, waiting and thanking.

\section{Social Conventions Belong to Our Way of Life}

Mollenhauer (1983/2003) and van Manen (1989, 1991/2006, 1997) both place an emphasis on the concrete pedagogical example in order for pedagogical research to sustain pedagogical practice. We take our point of departure in the concrete, evocative and lived experience-through descriptions where "the phenomenon is placed directly in the lifeworld so that the reader may experientially recognize it" (van Manen, 1997, p. 348). Along with Mollenhauer (1983/2003), we understand the pedagogical relationship metaphorically as the adult's thoughtful response to the child's call, and the sincerely and truthfully told or written description of the actual pedagogical situation to be the very core of pedagogical practice. Mollenhauer suggests:

If we accept the Augustinian metaphorical description of developmental preparedness [Bildsamkeit] as "call and response" then the self-reflexive relational story is the most appropriate form for the pedagogical subject to be described. The stories illuminate a theoretical thesis, that it is only possible to speak reasonably and action relevant of developmental preparedness [Bildsamkeit], when its creation is accounted for (p. 102).

In pedagogy, how do we account for what goes on between the adult and the child, me and the other? As Mollenhauer rightly reminds us, the pedagogical situation, and thus the pedagogical relation, is an immensely complex 'togetherness' that can be understood, although always insufficiently, through thoroughly reflected descriptions. But what does the description describe? Max van Manen (1991/2006) points to the significance of the good example in pedagogical inquiry. He says: "Pedagogical theorizing involves the study of good examples, of the goodness of examples of pedagogical action" (p. 218). What are the pedagogical qualities of human social conventions? How and what does the child 'call' from within the convention? How does the adult listen, or rather, is the voice of the child 'audible' to the adult, who is somehow experientially ensnared in the conventional atmosphere of the situation? How do adults respond to the 'call' of the child from within the conventional condition they are necessarily ensnared in? Adults and children seem to experience social conventions differently, and examples of how they may experience (sense, feel, understand) lived conventions of proper behaviour in the pedagogical relation is our focus here.

A significant part of our adult life with children is regular everyday life, where our being together is characterized by routines and social conventions rather than intentional actions and decisions. Mollenhauer's term 'way of life' (1983/2003) describes well this habitual way of living that adults by necessity share with children. He writes:

To the degree that we live with children, we have to-anything else is impossible-live our life together with them. We cannot extinguish ourselves as social beings; we cannot take up a dead 
or neutral position.... This may indeed be a triviality, but still it is the primary and most profound pedagogical fact of the case (p. 20).

The basic pedagogical condition in presenting a way of life for children is simply by living with them, which involves a multitude of important pedagogical and ethical concerns, and strongly touches upon the question of adult authenticity in concrete situations. In fact, the very informal nature of the presentation of a way of life challenges the idea of authenticity as a pedagogical quality, as the adult's pre-reflective understanding of him or herself and the personal and relational lifeworld, is directly presented and thus predominantly unreflected.

We intend though, to dwell with only a few relevant questions for the purposes of this paper, and we intend to do so by presenting a few lived experience descriptions from the interview material of this study. First, we will call attention to the difference between the adult and the child's experience of time and how this difference influences children and adults' ways of life, as well as their expectations of conventionally appropriate behaviour in pedagogical everyday-life situations.

\section{Social Conventions Anticipate Time}

Van den Berg (1970) reminds us of the fact that adults live primarily in the future and constantly occupy themselves with what should be done next. The connection between present and future in adult life is almost always possible to perceive. Van den Berg says: “...we [adults] are reluctant to repeat most of our actions. For action is the future realized, once done it definitely lies behind us" (p. 29). Thus, for adults, the future constantly turns into the present and a new future awaits ahead, hence repetition of actions is usually unwanted and seen as a waste of time. We know that for small children repetition is something experienced quite differently. Going on a bicycle ride together, we as adults usually have an idea of where we are going, or what we are supposed to do or see. Children may simply continue biking up and down the road because they enjoy riding over and over a particular bump as they are just taken up with the experience of biking itself. Biking up and down the road is exactly what young Alex in the movie Être et Avoir (Philibert, 2003) seems to take pleasure in on the bright vernal evening after school. Child-like, he seems to have somehow forgotten about any planned event he might have started out with, and stays with the very experience as it is in the moment.

On the other hand, we also know that adults as well might be conscious of the value of the present and try to stick to the experience of the moment. But this attitude is precisely that —an attitude, or an adjustment taken on with a certain conscious intention. As adults, we might value the moment because we know that a lifestyle that focuses on the present can contribute to better physical and mental health or improve one's life experience in general. Yet even if some adults by their lifestyle or profession live more in the moment than others, the child's dwelling in the present seems to be existentially different. Van den Berg appears to relate the difference between the adult and the child's way of being in the present to the quality of the present. He says: "This [the child's] forgetfulness is of a character quite different from any of our [adult] lapses of memory...The child lives in the moment more than the adult, in the pure present" (p. 30). Where is this pure present where the child lives? And might we somehow discern traces of the child's pure present in the 'shared' present, in the concrete situations of our common adult-child everyday life? Are we as adults somehow able to recognize the location of what we might call the genuine, true or even authentic presence of the child in the present? Where are we to look? Van den Berg and Buytendijk before him suggest that we look for the difference between the adult and the child's living or dwelling in the moment in the persons' experiential life world by trying to understand phenomenologically how he or she senses the direct day-to-day life with others (Van den Berg 1972, p. 39).

One of the commonly experienced situations of life where adults' conventional habits come to presence, is the habit of shaking hands, which according to van den Berg (1970, p. 28) is an act 
symptomatic of the human relation (but stronger in some cultures than in others). The convention of the handshake seems to be one of the cultural habitués that lingers on the edge between adult and children's life worlds. In our way of life with children, we tend to introduce hand-shaking to the child as an exemplary course of action (depending on the milieu), and we anticipate, though basically unconsciously, that the child shall adapt to this cultural habit. We do not usually plan to teach children the handshaking ability. The situation simply occurs when the child, always together with an adult- the adult either as the hand-shaker or as the one prompting the child to relate to the hand-shaker-is expected in the moment to relate to the conventionally expected behaviour.

Our human relationships are grounded in conventions, social norms and agreed-upon ways of life. Social conventions in a certain understanding, are the unreflected bonds between us, and particularly necessary in relational situations to initiate or establish contact and open up the possibility of a shared agenda. Social conventions are covenants shared by members of a society and are personally and culturally transferred from the older to the younger generations, still usually in unreflected ways as part of what Mollenhauer calls the 'way of life' or 'life-form'. Smaller children that are not yet initiated or only partly introduced to the conventional behaviour and agreed-upon social life have to learn how to behave through the example of adult practice.

\title{
Conventions of Proper Behaviour "Invisibles" the Child
}

Anne recounts the first time she, as a four year old child, accompanied her grandmother to her work place.

\begin{abstract}
Standing in the hallway after having left the elevator, grandmother tells me that behind this big, brown door she and two other women work at their office desks. She takes me by the hand and opens the door. "Hello, here come Anne and I", she says smilingly as she pulls me closer to her. Then all of a sudden she lets go of my hand and pushes me firmly in front of her toward one of the women who has gotten up to meet us (with her hand extended), saying to me, "Greet nicely now." I don't move and I say nothing. Then I slip behind my grandmother's legs.
\end{abstract}

This well-known situation of a child hiding behind an adult's legs when exposed to a stranger or to an unfamiliar condition is recognizable to most of us. In this situation, the safe hand of grandmother has been withdrawn from Anne. The child did not by herself let go of her grandmother's hand to greet the stranger. Rather, she seeks cover behind her grandmother's legs-the only safe place in this uncomfortable moment. But how is it that children hide behind the body of the adult in situations like these? The child might run away for example or lay down on the floor. The child might scream or cry rather than, as Anne did, remain silent and quiet. What is the child's experience of this particular moment when the adult, who acts rather unfaithfully, still seems to be the one the child seeks shelter with? Or we might ask, what makes the child remain in the situation and not simply shatter it by running away or screaming and crying? The child somehow seems bounded by invisible bonds. Anne perhaps somehow senses the bonds of expectation from the two women, one behind whose legs she is hiding herself, and the other standing in front of her with her hand expectantly extended. One might say that the expectation the child senses is the unreflected bonds of a social convention, which the grandmother unreflectedly imposes upon her.

Van den Berg (1970) describes a situation where a child who is asked to shake hands with an adult trustfully gives its little hand and unconditionally leaves it up to the adult to take responsibility for it. A situation different from the situation described above, but they have at least one trait in common: the child's passivity and one might say tameness. How might one understand these two situations pedagogically? Van den Berg suggests: “...the grownup who associates with a child, grows rather ill at ease at such docility. Active encounter on the child's part would be much easier for us than this utter 
trust" (p. 28). Somehow the conventional situation of shaking hands between adult and child seems to exclude the child as a real partner of action. The world of the child seems not yet to include social conventions like shaking hands. But what is more, in the world of the child, which is a world of unreservedness, the child cannot trust partially, but simply trusts or distrusts (Løgstrup 1971/1997). The child, who leaves it up to the adult to take care of his or her little hand, or as in the case of Anne's wordless withdrawal from shaking hands with the unknown woman, somehow calls to the adult to care and respond. In Old Norse the term trust from traust is related to the help or support one receives from someone who is firm and strong (Onions 1966, p. 946). Van Manen (1991/2006) and Løgstrup (1997) shed further light on this pedagogical point whereby the adult in a certain understanding is given his or her authority by the child. One might say that the child authorizes the adult to care responsibly until the child, him or herself, is able to take over the responsibility. Van Manen reminds us of this sensed and almost tangible experience of the child's authority that the adult might sometimes notice when he says: "The adult who is oriented to the child's vulnerability or need may experience a strange sensation-the true authority in this encounter rests in the child and not in the adult" (1991/2006, p.70). This seems to be true in moments when the adult senses that the child needs his or her help. But what if the adult is not aware of the child's vulnerability in a situation or if he or she does not see that the child needs help somehow? This might well be the situation when the social conventions of the adult world meet the world of the child. Somehow adults' ways and lives appear not to grant us access to the child's experiential world. Conventions of proper behaviour seem to shade or gloss our view of what the child before us needs. And we so easily forget about what it was like to be a child. We might want to be as close as possible to our children, still our 'grown-up-ness' somehow keeps us ignorant of how the child experiences the moment.

\title{
Bound by the Invisible Bonds of a Social Convention
}

A grown woman remembers a decisive moment from her early childhood:

\begin{abstract}
I am about four and I am standing by the gate in front of our house, waiting for my mother to get ready for our walk to the city centre. The woman in the neighbouring house comes by and stops in front of me, saying surprised: "Gee, are you still here?" She has been to the grocery shop. I vaguely remember her passing by while I was waiting for mother, but I don't know her name and we do not usually talk. From her bag a long green leek, sticks out. I also have a bag, but it is smaller and red and white. My mother lets me bring my bag when we go to the city or to the big grocery store together. The woman leaves and I wonder if I might run a little on the huge lawn? Or perhaps not. I might fall and smudge my tights or even rip them. I have smudged my tights before. I look at the swings on the playground. Will I get dirty if I try one of the swings?
\end{abstract}

The four year old is waiting for her mother to accompany her on their regular walk together. Mother has dressed and made the child ready before herself and told her to stay tidy until she has dressed and done all the last minutes things that mothers must do before they feel they can leave the house. But time passes and mother does not come. Even if the little girl is too young to estimate time, we know that she must have waited outside the gate a rather long time because of the neighbour woman who has been to the grocery shop and back while she stands there. As a reader we sense that the child has been waiting a very long time-perhaps too long for such a small child. But if the mother were asked, she most likely would experience time differently. Her efforts have been focused on the future and on all the things that she as a grown up is supposed to take care of before she can finally leave the house. On the contrary, the child lives in the pure present of the moment. She is not yet reflectively dedicated to the adult idea of time, nor is she attentive to the social conventions of waiting. Still she senses the 
bonds of the 'waiting norm' and adapts to them with obedience in much the same way that the young child hiding behind her grandmother's legs did. Both somehow mutely perceive the covenant established by the social convention of the life of which they are a part. They don't run away. They are in the situation in their own way. This is, of course, not unusual. Rather it is common and called the socialisation of children into the adult spheres of cultural life.

Of interest here, perhaps, is the pedagogical meaning of the difference between the adult and the child's worlds in terms of how the adult responds responsibility to what they cannot really know (Biesta 2006): the child's experience of the world. Mollenhauer (1983/2003) reveals to us that we have to look for traces left behind by the child, rather than call for evidence of how the particular child experiences the world. The child is both visible and invisible to us, he remarks. One might suggest that adult pedagogical being in a certain way is challenged by the demand of the unseen, partly forgotten and the mainly inaccessible world of the child. And even more pedagogically challenging, how do we respond responsively to the utter difference of the child's experience? How do we encounter the otherness of the child pedagogically when we, by necessity, are trapped in the social conventions of the grownup world?

\section{Social Conventions Expect Something in Particular: The Courteous Curtsey}

Etymologically the term convention connotes 'coming together', indicating literally the sense of physical meeting of people in one place, yet, the term also signifies the common habitual agreement of social norms within a society. A social norm or convention that belongs to a situation is more or less experientially known or sensed by the members of the current society, but usually at a pre-cognitive level. The social convention expects certain behaviors and rejects others. One may wonder however, if non-members or not-yet-members, also in a certain understanding have this sensed knowledge. Through the anecdotes provided by the adults above, their experiences as children of both greeting a stranger and waiting as expected, somehow gives the impression that children sense the structures or the meaning of social conventions through the adults' presentation and representation of them. Children seem to be sensitive to what is expected of them, even if they are not yet initiated into the actual convention of proper behavior or reflectively able to make sense of the expectation that is directed at them. What does this innate sense of social conventions for the not-yet-members of a society mean pedagogically? Is this simply the way we are taught conventional actions, socialized into a particular social community, or is there more at stake pedagogically? Do social conventions and conventional expectations mean something to the child's experience of self? What is going on in the moment that the child meets the convention of expected proper behavior?

Mollenhauer (1983/2003) reminds us of the fact that we cannot but present our value based selection of a mediated or interpretable world to children. He says, "When we present the world to children, we do not present the world, but what we see as the world. We show them what to us seems to be worth showing from what we see as the world" (p.77). The way we see the world and what seems to us to be worth representing to children thus is mainly functional and only partly intentional. Habitual practices and social conventions are per se related to the part of our pedagogical practice that is prereflective and non-conscious but nevertheless a practice that shows-through in our ways of life, and discloses particular expectations of the children we encounter. Løgstrup (1971/1997) shows us that the more precise the social norms and conventions are "the easier it is to determine whether or not a person is living in harmony with them. This in turn enables us to react in specific ways to any acts of disobedience" (p. 58). The sense of disharmony in being a foreigner and unsuccessfully trying to adjust to unfamiliar customs of courtesy is what fourteen year old Kari remembers more than 30 years after the fact: 
My friend Stine and I have always lived in Norway, but her father is from England. The summer we were fourteen Stine, her father and I went together to Great Britain. We were visiting her father's parents and some other members of his family. The first evening we were having dinner with the entire family, and everybody seemed to be enjoying themselves. We were eating and commenting on the delicious food, talking in English of course, and laughing a lot. In all this I had the strong sense that they were much more refined and well-mannered than I was used to, and this made me uncertain and tense. Their utter politeness evoked in me a disquieting feeling of not being one of them. Much of what they said went over my head, and I could not share in their jokes. I realized that I was not even familiar with the correct polite phrase by which they would express their gratitude for the lovely food. (Surprisingly fast the dinner was over and) when we were about to leave the table, I sensed that the hostess of the family, the mother, was looking at me and smiled. I took it that she expected something from me, and smiled back somewhat anxious. When we met a moment later, I stretched my right hand toward her and said (curtseying): "Thank you for the meal!" Her smiling expression turned surprised and then went blank, as she withdrew her hand discreetly. I immediately knew that something was wrong. But what? I was left without a clue.

What was at stake here for Kari? Being unfamiliar with the social conventions that the other persons around the table seemed to share, placed her in a position of seclusion. The moment she is met, not with recognition, but rather with discordant reticence, she is thrown into a state of lived isolation. The social convention that according to Løgstrup (1971/1997) is a means of protection from being psychically and privately exposed doesn't protect her. This protective function of the social convention seems to become operational only when one meets the expectation of the convention. It is as Løgstrup says,

Regardless of how these forms originated, they facilitate our relationship with one another, making it smooth and effortless, not least they protect us against psychic exposure. Without the protection of the conventional norms, association with other people would be intolerable (p. 19-20).

But Løgstrup's insight seems to pertain exclusively to adults or persons that are initiated into the social conventions. When we are initiated into the convention of proper behavior and do not disobey the roles or the language that the convention demands, then the subservience to the social convention somehow protects us from personal, negative exposure. But for Kari or children like her, who are notyet-members of the conventional community and make mistakes being that they are not yet socialized, or do not understand the language of the social convention, then the convention exposes and lays open their non-understanding to others. Moreover, because of the unreflected nature of the social convention, the adult's response to the child's call for understanding and guidance may not be attributed to the unfamiliarity of the convention of proper behaviour but rather to other things like general disobedience, a lack of will or sheer obstinacy.

Logstrup shows that "we constantly live in a state of being already delivered—either through a passing mood or in terms of something which in a fundamental way affects our entire destiny. We are therefore subject to being exploited" (1971/1997, p. 57). Is this also true for children, and perhaps in particular for children in habitual and socially conventional situations where the adult is not intentionally prepared to protect the child? To Løgstrup our exposed situation in relation to others is not a result of deliberate delivery but rather it is simply part of life, irrespective of any personal decision. What does this mean for children? Are they more delivered, more exposed? And in situations where conventional behaviour is expected and their call for pedagogical support cannot be responded to because of the very nature of the conventional situation, is pedagogical care and thoughtfulness even possible? 


\section{Social Conventions Anticipate Homogeneity}

The pedagogical situation where a specific conventional behavior is anticipated can be understood as a call for sameness, conformity and the ruling order of things. Thus, the intention of asking the child to conform by rendering invisible his or her uniqueness in favor of similarity, is the objective of the socially conventional adult. Lippitz (1990) compares the indirect traditional conforming pedagogical relation to the direct face to face relation described by Levinas, and concludes that "the establishment of a pedagogical responsibility ensues from the internal pedagogical dimension of the ethical relation"(p. 59) (the author's italics). One may argue though, for an even closer relationship between pedagogy and ethics, and for the personal, responsible, reliable pedagogical relation as a relation sui generis (Spiecker, 1984), a relation that is ethical to the core. According to Continental philosophy, ethics is not primarily a form of thinking or logic reasoning, but a particular practice/praxis directed toward the other (Heidegger, 1926/1962; Levinas, 1998, 2002, Dunne 2001). The pedagogic intention for practice with children is here understood as a profoundly ethical praxis; a thoughtful concern for the child's unique person and for the uniqueness of the situation (Nohl, 1970; Langeveld, 1975, 1983; Mollenhauer, 1983/2003; Bollnow, 1968/1989, van Manen, 1991/2006, 2002). Thus, one might suggest that pedagogic practice is pedagogical and ethical at the same time. If the relation between the adult and the child should be interpreted as a pedagogical relation, the pedagogical and the ethical are not only intertwined, but have never been separate (Saevi, 2007, p. 126). Heidegger reflects the unity between ethics and action when he demonstrates that selfhood and the relation to the other are ways of existing rather than psychological entities that we can define in terms of their presence. He argues along with Kierkegaard for the active existential and personal choice in order not to be trapped in inauthenticity and "carried along with the nobody" (1926/1962, p. 312). Heidegger seems to see the inauthentic condition of the human being as a being lost in the 'they' (p. 313) whereby the detour to potential authenticity has to be revealed in order for the person to re-find authenticity. The claim on the person to choose authenticity, Heidegger calls "resoluteness" (p. 344), and when this resoluteness is authentic it shows itself in a caring way of being in the world with others. "Resoluteness brings the Self right into its concernful Being-alongside what is ready-to-hand, and pushes it into solicitous Being with Others" (p. 344). For the person to (temporarily) retrieve his or her authentic being, the person, according to Heidegger, should orient him or herself to consideration and care for the other. The condition of willed care for and solicitous dwelling with the other constitutes a situation of direct coexistence between myself and the other. In this situation the other remains other, unique, unknown to me. This constitution of the intersubjective ethical relation is heterogeneous "for it assumes the radical separation of the interacting parties and thus acknowledges their respective uniqueness and otherness" (Lippitz, 1990, p. 51). Løgstrup (1971/1997) however, points to a basic dilemma between social conventions and ethics in reference to ethical pedagogical practice. Care and concern for the other by responding directly and personally to his or her silent demand of trust, in the socially conventional situation, tends to be replaced by the unreflected concern of satisfying the social convention and the demand of the social norm. He says, "Social convention has the effect of reducing both the trust that we show and the demand that we take care of the other person's life" (p. 19). What does this mean in terms of a socially conventional practice with children?

Children cannot liberate or entirely rid themselves of the views and aims of the adult and the adult world, nor can the adult take up a neutral or value free position that does not influence the child, the relation between them, and the adult self. Thus the precondition of intentionality of the pedagogical relation questions, by its very existence, the meaning of socially conventional actions and procedures of socialization. Like in every educational approach, pedagogy and pedagogical practice can become means to a predetermined end, rather than being the end itself. The pedagogic intention may lose its focus on the good of the child and begin to serve other purposes, for example the purpose of a particular educational system, a political or religious belief or a socially beneficial outcome. Lippitz (2007) analyzes a range of former and recent examples of pedagogical practice or theory of practice from 
within the European pedagogical tradition called Bildung. Bildung, he notes, tends to start in the selfawareness of imperfection and openness to the unique child, but ends up theoretically consuming the experienced otherness and foreignness of self and other. He says,

That which is other and foreign becomes simply a means to Bildung, and carries no other purpose in itself. When the other or foreign becomes knowledge, it is always presupposed that the otherness or foreignness is not fundamentally different in comparison to the consciousness which experiences and reflexively appropriates it. It ceases to be something that is known even its foreignness, and becomes a part of reflexive consciousness. The initial difference between the self and the other, the starting point of the self and the knowledge of the other, is effectively erased. It disappears in the sameness of reflection (p. 84).

Lippitz perceives that traditional pedagogy i.e. Bildung, seems to see the otherness and foreignness of the child only as a temporary transition or passage to leave behind on the way to a generalized knowledge and a common outcome of education. Education as a project that by necessity is personal, risky and profoundly dependant on trust and uncertainty (Bollnow, 1969, Biesta, 2006) has been traded for a productive and effective epistemology. Lippitz appropriately indicates that originally the uniqueness and foreignness of the child was basic to humanistic pedagogy, but "foreignness does not experience any dramatic amplification when the goal of education is taken to be the integration of the young into the continuities and traditions of adult generations" (2007, p. 88). To integrate or socialize children into the social conventions of the existing, into the covenant conformity of society, means to render them social, to expect them to mingle to blend in, to be assimilated rather than standing out in their unique foreignness. Education as socialization into social conventions and norms, is basically to adjust the child to the ruling order, to promote homogeneity, unity, amalgamation, consumption of the child, and to make the child "understandable and treatable" (p. 90). Lippitz asserts along with Levinas that, "A constituent part of ethics is the absolute separation between myself and the Other. Heterogeneity, not unity and reciprocity, is the characteristic of the ethical situation. In this situation I, as the only subject, am irreplaceable" (1990, p. 50). Can we in the pedagogical situation where the child is expected to perform a certain convention of proper behaviour, recognize and care for the child's foreignness and uniqueness, especially when the child's lack of conformity profoundly disturbs the usual conventional order? Can we somehow protect the pedagogical qualities in not making the child equal, the likes of me, someone I already know? Or is the social convention by its very nature always aiming for homogeneity?

\section{The Social Convention Is Blind to the Otherness of the Child}

Socially conventional situations with children, like the ones described above, do not seem to be concerned with unique and irreplaceable subjects, but are rather situations of assimilation and the limitation of foreignness. Somehow the social convention is blind to the otherness of the child. In the social convention and by the expectation of proper conventional behaviour, we see the child indirectly, with continuity and profoundly "unthinkingly" (Saevi, 2005, p.183) rather than directly and with the possibility of discontinuity (Bollnow, 1969). We do not expect something unique or other, but rather we see the child in the continuity of what it has been so far, without the potential of something new. We are somehow conditionally blinded by our habitual practice and social conventions so that the child in a sense remains unconscious to our vision as a unique and unconventional child in a particular situated context. The quality of the social convention makes it something we do not actively choose; something we see without reflectively being aware of it. Thus it seems that the social convention and pedagogical care mutually exclude each other. Max van Manen, though (1991/2006), reminds us that routines and habits in themselves are not necessarily pedagogically bad and points to the pedagogical 
meaning behind habitual practices with children. He says, "Children not only need to be stimulated by new and challenging learning experiences, but also they benefit from the trust and security created by routines and habits grounded in past reflective pedagogical decisions" (p. 120). But are not pedagogically pre-reflected habits different from cultural social conventions? A social convention, unlike a pedagogical habit, is not necessarily reflected by the adult to be a personally useful and flexible practice beneficial to the child. A social convention is rather commonly unreflected and thus practiced by the adult in ways that are not necessarily either valuable or meaningful to the unique child. Løgstrup $(1971 / 1997)$ stresses that social norms and conventions oblige limits of certain forms of power and violence of one person toward another, and in this sense they are based on reason. This is so even though social conventions and norms are not necessarily rationally created to help persons defend themselves, to keep up social order, or to make social life smooth and frictionless. He concludes that, "their [law, morality and convention] actual rational function does not ... account for their origin" (p.57). Even though habits, social norms and conventions once may have been conscious perceptions and reflective decisions, they have turned into the shadow land of unawareness and non-reflectivity over the process of time.

Social conventions belong to our way of life and constitute significant and unattended to aspects of the relation between adult and child. But it is always possible for social norms and conventions in regards to certain appropriate behaviors to become reflective to us and hence subject to our intentional consideration and choice. We may, for example, become attentive to aspects of the lived experience of shaking hands, or the meaning of waiting for a small child, and decide to pedagogically care for the child who finds himself or herself in an unfamiliar situation. Our level of reflection thus can somehow turn the social convention into a non-convention, or perhaps more correctly, the aspects of the social convention that we are able to recognize and render familiar to the child, make it less the unreflected social convention it once was. However, the nature of social conventions prevent us from recognizing them beforehand and the complexity of even the most familiar pedagogical situation veils the lived meaning of it for the other, the child. We can only wonder what is really at stake in the socially conventional situation for the child - to the subjective, unknown and partly hidden and mysterious child. Mollenhauer (1983/2003) has demonstrated that pedagogical practice fundamentally is subject to the condition of being dead-locked. Although at the same time, pedagogical actions and options often have alternatives, and every childhood could be potentially different, he says,

Education and formation is always a process of expansion and enrichment, but at the same time, is also a process of constriction and impoverishment of what would have been possible. Adults not only are midwives in children's development, but also for children are powerful censors of that which is part of their formation (p. 10).

The relation between adult and child, in a conventional sense of the term relation, involves a more or less systematic and thorough attempt by the adult of effecting and directing the child in desirable directions by simultaneously "comparing, [and] mediating the personal relationship by general norms and standards" (Lippitz, 1990, p. 49).

How then is the socially conventional action experienced in the moment of acting? How does the adult sense the child and the practice as the practice taking place? Does the grandmother who encouraged Anne to shake hands with her colleague, or the mother who instructed her daughter to wait in front of the gate for such a long time, or the adults in the company of the young girl who fell short of understanding the foreign meal custom, in fact sense what was at stake in the situation for the child? The adult is part of the situation with the child but nevertheless the meaning of the event for the child with regard to significant aspects seems to be unattainable for the adult. One might say that the child "is seen, but not noticed" by the adult (Saevi, 2005, p. 186). The character of the social convention prevents the adult from taking notice of what is really going on with the child in the situation. In other 
words, the conventionally trained adult is not aware of what is seen in the moment of seeing (p. 187). Social conventions being inevitable and unalterable, and at times even useful and efficient guides to social and educational life and practice, lack the pedagogical qualities that serve the unique and irreplaceable child. The pedagogical impasse of the social convention that makes the child "old" before he or she has a chance to be young" (Lippitz 2007, p. 90) blurs trust and pedagogical thoughtful care, and assimilates the child in pre-determined conformity of social surrender. And although culturally unchangeable, social conventions should pedagogically remain a constant challenge. Without the possibility of stepping outside of social conventions or to permanently overcome our self-centred striving for sameness and synchronization of views and wills, our challenge as adults and pedagogues is to become more attentive to the experience of the child and to acknowledge the child's utter otherness as the basic precondition for pedagogical relational practice.

\section{References}

Biesta, G.J.J. (2006). Beyond education. Democratic education for a buman future. London: Paradigm Publishers.

Bollnow, O.F. (1968/1989). The pedagogical atmosphere. Phenomenology + Pedagogy, 7, 5-63.

Bollnow, O.F. (1969). Eksistensfilosofi og pedagogike. Oslo: Fabritius.

Dunne, J. (2001). Back to the rough ground. Practical judgment and the lure of technique. Indiana: University of Notre Dame Press.

Heidegger, M. (1926/1962). Being and time. San Francisco: Harper \& Row.

Langeveld, M. (1975). Personal help for children growing up. The W. B. Curry Lecture delivered in the University of Exeter on November 8, 1975.

Langeveld, M. (1983). Reflections on Phenomenology and Pedagogy. In: Phenomenology + Pedagogy, 1(1), $5-10$.

Lippitz, W. (1990). Ethics as Limits of Pedagogical Reflection. In: Phenomenology + Pedagogy, 8, 49-60.

Lippitz, W. (2007). Foreignness and Otherness in Pedagogical Contexts. In: Phenomenology \& Practice, 1(1), 76-96.

Levinas, E. (1998). Entre nous. Thinking of the other. New York: Columbia University Press.

Levinas, E. (2002). Time and the other. Pittsburgh: Duquesne University Press.

Løgstrup, K.E. (1971/1997). The ethical demand. Notre Dame, IL: University of Notre Dame Press.

Løgstrup, K.E. (1997). System og symbol. Copenhagen: Gyldendal.

Mollenhauer, K. (1983/2003). Vergessene zusammenhänge. Über kultur und erziebung. München, DE: Juventa Verlag.

Nohl, H. (1970). Die Pädagogische Bewegung in Deutschland und ihre Theorie. Frankfurt, DE: Vittorio Klostermann.

Onions, C.T. et al. (Eds.). (1966). The Oxford dictionary of English etymology. Oxford: Clarendon Press.

Philibert, N. (Director). (2003). Etre et avoir [motion picture]. France: Canal+.

Saevi, T. (2005). Seeing disability pedagogically: The lived experience of disability in the pedagogical encounter. Bergen: University of Bergen Press.

Saevi, T. (2007). Den pedagogiske relasjonen-en relasjon annerledes enn andre relasjoner. [The Pedagogical Relation-A Relation Different from Other Relations]. In O. Kaldestad et.al. (Eds.). Grunnverdier og pedagogike. [Basic values and education]. Bergen, NO: Fagbokforlaget.

Stilma, L. (1985). Portraits. New York / London: Mosaic Press.

Spiecker, B. (1984). The pedagogical relationship. Oxford Review of Education, 10(2), 203-209.

van den Berg, J.H. (1970). Things—four metabletic reflections. Pittsburgh, PA: Duquesne University Press.

van den Berg, J.H. (1972). A different existence. Pittsburgh, PA: Duquesne University Press.

van Manen, M. (1989). By the light of the anecdote. Phenomenology + Pedagogy, 7, 232-253.

van Manen, M. (1991/2006). The tact of teaching. London, ON: The Althouse Press. 
van Manen, M. (1997). From meaning to method. Qualitative Health Research: An International, Interdisciplinary Journal, 7(3), 345 -369.

van Manen, M. (2002). The tone of teaching. London, ON: The Althouse Press.

\section{About the Authors}

Tone Saevi is Associate Professor of Pedagogy and Phenomenology. Heidi Husevaag is Assistant Professor of Education. Both are at the Norwegian Teacher Academy in Bergen, Norway. 